\title{
Analisis Pendapatan dan Kelayakan Usahatani Jagung di Kecamatan Patilanggio Kabupaten Pohuwato Provinsi Gorontalo
}

\author{
Ulfira Ashari ${ }^{1 *}$ \\ ${ }^{1}$ Departemen Agribisnis, Fakultas Pertanian, Universitas Ichsan Gorontalo \\ *Corresponding author: ulfira1989@gmail.com
}

\begin{abstract}
Abstrak
Jagung merupakan komoditi unggulan di Provinsi Gorontalo digunakan sebagai bahan baku pakan ternak yang mampu menembus pasar internasional. Salah satu sentra jagung di Provinsi ini terletak di Kecamatan Patilanggio dengan mayoritas petani mengusahakan komoditi jagung sebagai mata pencaharian utama. Oleh karena itu, penelitian ini dilakukan dengan tujuan untuk menganalisis pendapatan dan kelayakan usahatani jagung di Kecamatan Patilanggio, Kabupaten Pohuwato, Provinsi Gorontalo. Penelitian dilakukan dari bulan Maret hingga April 2020. Teknik pengumpulan data melalui observasi dan wawancara menggunakan kuesioner. Pengambilan sampel petani dilakukan dengan metode simple random sampling sebanyak 40 orang. Analisis data menggunakan analisis pendapatan dan perhitungan $\mathrm{B} / \mathrm{C}$ ratio. Hasil penelitian menunjukkan usahatani jagung di Kecamatan Patilanggio menguntungkan dengan rata-rata pendapatan responden sebesar $\mathrm{Rp}$ 12.317.515/MT dari total biaya sebesar Rp 6.144.985/MT. Analisis kelayakan menunjukkan nilai B/C ratio sebesar 2, sehingga usahatani jagung di Kecamatan Patilanggio tergolong layak dijalankan.
\end{abstract}

Kata kunci: B/C ratio, Pendapatan, Usahatani jagung

\begin{abstract}
Corn is a leading commodity in Gorontalo Province used as raw material for animal feed which is able to penetrate the international market. One of the corn centers in the province is located in Patilanggio District, with the majority of farmers cultivating corn as their main livelihood. Therefore, this study was conducted with the aim of analyzing the income and feasibility of corn farming in Patilanggio District, Pohuwato Regency, Gorontalo Province. The study was conducted from March to April 2020. The data collection technique was through observation and interviews using a questionnaire. Sampling of farmers was carried out by simple random sampling method of 40 people. Data analysis used income analysis and $B / C$ ratio calculation. The results showed that corn farming in Patilanggio District was profitable with an average income of Rp. 12,317,515 / MT from the total cost of Rp. 6,144,985 / MT. The feasibility analysis shows the B / C ratio value of 2, so that corn farming in Patilanggio District is classified as feasible to run.
\end{abstract}

Keywords: B/C ratio, Income, Corn farming 
Prosiding Seminar Nasional Pembangunan dan Pendidikan Vokasi Pertanian

Politeknik Pembangunan Pertanian Manokwari, 14 November 2020

e ISSN : 2774-1982

\section{PENDAHULUAN}

Pertanian merupakan sektor primer yang memiliki peranan penting dalam menjaga pertumbuhan ekonomi di Indonesia melalui peningkatan Produk Domestik Bruto (PDB), devisa negara, pengentasan kemiskinan serta penyedia lapangan kerja. Sektor ini mampu menyerap tenaga kerja hingga 35\% dibandingkan sektor lainnya yang berperan dalam peningkatan pendapatan per kapita masyarakat Indonesia. Pertanian juga berkontribusi secara tidak langsung terhadap pemenuhan bahan baku industri pangan, yang selanjutnya berdampak pada ketahanan pangan dalam negeri (Khairiyakh et.al, 2015).

Ketahanan pangan merupakan salah satu program yang diterapkan pemerintah untuk mengoperasionalkan pembangunan baik tingkat nasional maupun masyarakat (Nugroho, 2015). Program ini mencakup masalah ketersediaan, distribusi dan konsumsi pangan. Ketersediaan pangan diwujudkan dengan tercukupinya kebutuhan pangan penduduk baik segi kuantitas, kualitas, keragaman, dan keamanannya. Distribusi pangan menyangkut keberlanjutan pangan dengan harga yang terjangkau. Konsumsi pangan mencakup masalah pemenuhan gizi, keamanan, dan kehalalannya. Dalam hal ini, kebutuhan pangan dalam negeri semakin meningkat seiring dengan peningkatan populasi penduduk. Akan tetapi, lahan pertanian di Indonesia semakin sempit karena dialihfungsikan menjadi pemukiman, dan lahan industri (Prabowo, 2010). Hal ini menjadi tantangan bagi petani yang dituntut berproduksi secara optimum agar mampu meningkatkan pendapatannya.

Jagung adalah salah satu komoditi pertanian yang mendukung ketahanan pangan selain beras. Jagung tumbuh subur dan popular di Indonesia memiliki banyak manfaat diantaranya sebagai sumber karbohidrat, antioksidan serta bahan baku industri (Ginting et.al, 2020). Provinsi Gorontalo termasuk dalam 10 wilayah yang mempunyai kontribusi terbesar terhadap produksi jagung nasional. Komoditas ini telah digalakkan sebagai komoditi unggulan Provinsi Gorontalo sejak tahun 2002. Pemerintah Provinsi berusaha meningkatkan produksi jagung dengan melakukan peningkatan luas areal tanam. Pada tahun 2016 , produksi jagung meningkat sebesar 911.341 ton karena adanya peningkatan luas panen sebesar 195.606 hektar dengan luas tanam mencapai 225.000 hektar (NSLIC, 2018). Komoditi jagung di Provinsi Gorontalo mampu menembus pasar jagung internasional, tidak hanya diperuntukkan sebagai bahan pangan melainkan juga sebagai bahan baku pakan ternak.

Produksi jagung terbesar di Provinsi Gorontalo terletak di Kabupaten Pohuwato. BPS Provinsi Gorontalo (2018) mencatat bahwa produksi jagung Kabupaten Pohuwato 
Prosiding Seminar Nasional Pembangunan dan Pendidikan Vokasi Pertanian Politeknik Pembangunan Pertanian Manokwari, 14 November 2020

e ISSN : 2774-1982

berkontribusi sekitar 48 persen dibandingkan kabupaten lainnya di Provinsi Gorontalo. Kecamatan Patilanggio berada di peringkat kedua sebagai daerah penghasil jagung terbesar di Kabupaten Pohuwato setelah Kecamatan Randangan. Tahun 2015, produktivitas jagung di Kecamatan Patilanggio mencapai 7,2 ton/ha melebihi produktivitas kabupaten yang hanya mencapai 6,4 ton/ha. (BPS Kabupaten Pohuwato, 2016). Hal ini menunjukkan bahwa usahatani jagung berpotensi untuk dikembangkan petani di Kecamatan Patilanggio.

Penelitian tentang pendapatan usahatani jagung telah banyak dijumpai. Salah satunya pada penelitian Agustyari et.al (2013) tentang perbandingan pendapatan usahatani jagung manis dan padi. Penelitian ini hanya mengambil sampel petani di Subak Delod Sema Padanggalak yakni salah satu wilayah di Desa Kesiman Petilan Kecamatan Denpasar Timur. Hasil penelitian menunjukkan bahwa usahatani jagung menghasilkan pendapatan lebih tinggi dibandingkan usahatani padi. Sari et.al (2014) menganalisis pendapatan dan tingkat kesejahteraan rumah tangga petani jagung di Kecamatan Lampung Selatan. Pada penelitian ini, sampel petani yang menjadi responden diambil berdasarkan lingkup desa. Analisis kelayakan usahatani jagung menggunakan kriteria $\mathrm{R} / \mathrm{C}$ ratio dengan hasil penelitian menunjukkan bahwa pendapatan petani jagung berada dalam kategori cukup dan sejahtera.

Penelitian serupa juga dilakukan oleh Purwanto et.al (2015) tentang analisis produksi dan pendapatan usahatani jagung hibrida di Desa Modo Kecamatan Bukal Kabupaten Buol. Penelitian ini menggunakan model regresi berganda untuk menguji faktor-faktor yang mempengaruhi produksi. Hasil penelitian menunjukkan bahwa luas lahan, benih, pupuk, dan tenaga kerja mempengaruhi produksi jagung. Tahir (2017) menganalisis pendapatan usahatani jagung dengan membandingkan lahan sawah dan tegalan. Penelitian ini mengambil sampel dalam lingkup kecamatan tepatnya di Kecamatan Ulaweng Kabupaten Bone Sulawesi Selatan. Analisis pendapatan dilengkapi dengan perhitungan R/C ratio. Hasil penelitian menunjukkan usahatani jagung di lahan sawah memberikan pendapatan lebih besar dibanding lahan tegalan. Palobo et.al (2019) juga meneliti tentang kelayakan usahatani jagung hibrida pada lahan kering di Merauke Papua. Penelitian ini mengukur kelayakan menggunakan R/C ratio, B/C ratio, Break Even Point, dan analisis imbalan kerja. Hasil penelitian menunjukkan bahwa usahatani jagung hibrida di lahan kering layak dilaksanakan dan menguntungkan.

Berdasarkan uraian latar belakang dan kajian penelitian terdahulu, tujuan dari penelitian ini adalah untuk menganalisis pendapatan dan kelayakan usahatani jagung di Kecamatan Patilanggio Kabupaten Pohuwato Provinsi Gorontalo. Penelitian ini 
Prosiding Seminar Nasional Pembangunan dan Pendidikan Vokasi Pertanian Politeknik Pembangunan Pertanian Manokwari, 14 November 2020

e ISSN : 2774-1982

menggunakan metode analisis serupa dengan penelitian lainnya, yakni menghitung pendapatan usahatani jagung dengan mencari selisih antara penerimaan dan biaya usahatani. Akan tetapi untuk kelayakan usahatani, peneliti hanya menggunakan analisis $\mathrm{B} / \mathrm{C}$ ratio dengan membandingkan pendapatan dan biaya. Penelitian dilakukan dengan mengambil sampel dalam lingkup kecamatan yang diwakili dari beberapa desa yang memiliki produksi terbesar di wilayah tersebut. Oleh karena itu, penelitian ini dianggap penting dan menarik untuk dilaksanakan. Melalui penelitian ini diharapkan berbagai pihak yang terlibat dalam usahatani jagung dapat memperoleh informasi yang dijadikan sebagai bahan pertimbangan dalam merumuskan kebijakan yang terkait dengan upaya peningkatan pendapatan dan kesejahteraan bagi petani jagung.

\section{METODE}

\section{Waktu dan Tempat Penelitian}

Penelitian ini dilaksanakan sejak bulan Maret hingga April 2020. Pemilihan tempat penelitian dilakukan dengan sengaja (purposive) dengan pertimbangan bahwa Kecamatan Patilanggio merupakan salah satu sentra produksi jagung di Kabupaten Pohuwato, tepatnya di Desa Suka Makmur dan Dudepo sebagai representatif kecamatan.

\section{Jenis dan Sumber Data}

Penelitian ini menggunakan data sekunder dan data primer. Data sekunder diperoleh dari kantor desa berupa data karakteristik responden, serta dari BPS berupa data produksi jagung di lokasi penelitian. Data primer merupakan data yang diperoleh dari hasil wawancara dengan responden berupa data jumlah produksi jagung tiap musim tanam, penggunaan sarana produksi, alat-alat pertanian, dan data pendukung lainnya sesuai dengan kusioner penelitian.

\section{Teknik Pengumpulan Data}

Pengumpulan data penelitian diperoleh melalui observasi dan wawancara dengan responden. Observasi merupakan pengamatan langsung bertujuan untuk melihat keadaan usahatani jagung di lokasi penelitian yang menjadi dasar untuk mengangkat isu permasalahan yang akan diteliti. Wawancara responden dilakukan menggunakan kuesioner yang telah disusun untuk mencapai tujuan penelitian.

\section{Populasi dan Sampel Penelitian}

Populasi dalam penelitian ini adalah semua petani yang mengusahakan komoditi jagung yang terdapat di Kecamatan Patilanggio. Populasi di lokasi peelitian sebanyak 526 orang. Pengambilan sampel petani dilakukan dengan metode simple random sampling 
Prosiding Seminar Nasional Pembangunan dan Pendidikan Vokasi Pertanian

Politeknik Pembangunan Pertanian Manokwari, 14 November 2020

e ISSN : 2774-1982

dengan perhitungan jumlah sampel menggunakan rumus Slovin dengan nilai error sebesar $15 \%$, sehingga diperoleh sampel sebanyak 40 petani.

\section{Metode Analisis Data}

Untuk mencapai tujuan dalam penelitian dilakukan tahapan analisis data sebagai berikut:

\section{Pendapatan Usahatani}

Sebelum analisis pendapatan, terlebih dahulu dilakukan perhitungan penerimaan usahatani. Penerimaan usahatani merupakan hasil dari perkalian jumlah produksi dan harga jual tiap produk pada periode waktu tertentu yang dinilai dalam satuan rupiah (Setiawan dan Basri, 2017). Adapun rumus penerimaan usahatani jagung sebagai berikut:

$\mathrm{TR}=\mathrm{Y} . \mathrm{Py}$

Keterangan:

$$
\begin{array}{ll}
\mathrm{TR} & =\text { total revenue }(\text { penerimaan}) \\
\mathrm{Y} & =\text { yield }(\text { produksi) } \\
\mathrm{Py} & =\text { product } \text { price }(\text { Harga })
\end{array}
$$

Selanjutnya menganalisis struktur biaya usahatani jagung. Suratiyah (2006) menjelaskan total biaya usahatani diperoleh dengan menjumlahkan total biaya tetap dan biaya variabel. Secara matematis dituliskan sebagai berikut:

$$
\mathrm{TC}=\mathrm{TFC}+\mathrm{TVC}
$$

Keterangan:

$$
\begin{array}{ll}
\mathrm{TC} & =\text { total cost } \text { (biaya usahatani) } \\
\mathrm{TFC} & =\text { total fixed cost } \text { (biaya tetap) } \\
\mathrm{TVC} & =\text { total variable cost } \text { (biaya variabel) }
\end{array}
$$

Biaya tetap merupakan pengeluaran usahatani yang jumlahnya tetap pada berbagai tingkat output yang diproduksi. Biaya tetap meliputi pajak lahan, sewa lahan, serta penyusutan alat. Sedangkan biaya variabel merupakan bentuk pengeluaran usahatani yang jumlahnya berubah-ubah tergantung besarnya produksi. Biaya variabel 
Prosiding Seminar Nasional Pembangunan dan Pendidikan Vokasi Pertanian

Politeknik Pembangunan Pertanian Manokwari, 14 November 2020

e ISSN : 2774-1982

meliputi biaya pembelian benih, pupuk, pestisida, serta biaya penggunaan tenaga kerja (Nurwibowo et al, 2013).

Pendapatan usahatani merupakan selisih antara penerimaan dan biaya usahatani (Soekartawi, 2003; Nurwibowo et.al, 2013; Palobo et.al, 2019). Secara matematis dinotasikan sebagai berikut:

$\mathrm{Pd}=\mathrm{TR}-\mathrm{TC}$

$$
\begin{aligned}
& \text { Keterangan: } \\
& \begin{array}{ll}
\mathrm{Pd} & =\text { Pendapatan usahatani jagung } \\
\mathrm{TR} & =\text { total revenue (penerimaan) } \\
\mathrm{TC} & =\text { total cost (biaya usahatani) }
\end{array}
\end{aligned}
$$

\section{Kelayakan Usahatani}

Kelayakan usahatani jagung diukur menggunakan benefit cost ratio (B/C ratio).

$\mathrm{B} / \mathrm{C}$ ratio merupakan perbandingan antara pendapatan dengan total biaya usahatani (Hendayana, 2016; Palobo et.al, 2019) . Secara matematis dituliskan sebagai berikut:

$$
\mathrm{B} / \mathrm{C} \text { ratio }=\frac{P d}{T C}
$$

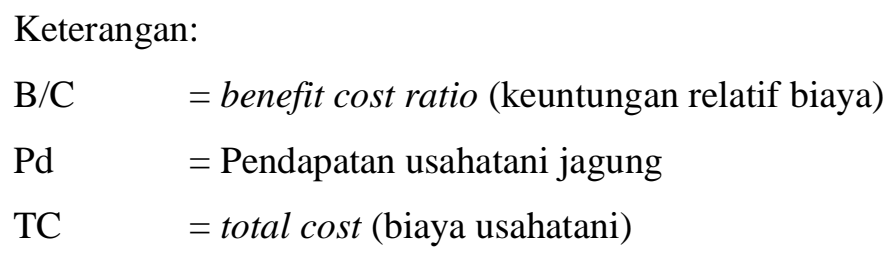

\section{HASIL DAN PEMBAHASAN}

\section{Karakteristik Responden}

\section{Tingkat Umur Responden}

Umur menjadi indikator dalam mengukur produktivitas kerja disebabkan berkaitan dengan kemampuan fisik seseorang dalam melakukan suatu pekerjaan. Responden yang berada pada umur produktif cenderung lebih kuat dari segi fisik dibandingkan non produktif. Semakin tinggi umur responden maka produktivitas kerjanya semakin menurun (Ukkas, 2017). 
Prosiding Seminar Nasional Pembangunan dan Pendidikan Vokasi Pertanian Politeknik Pembangunan Pertanian Manokwari, 14 November 2020

e ISSN : 2774-1982

Tabel 1. Klasifikasi Responden Menurut Umur, Tahun 2020

\begin{tabular}{ccc}
\hline Umur (Tahun) & Jumlah Responden (Orang) & Persentase $(\%)$ \\
\hline $22-27$ & 8 & 20,00 \\
\hline $28-33$ & 6 & 15,00 \\
\hline $34-39$ & 8 & 20,00 \\
\hline $40-45$ & 8 & 20,00 \\
\hline $46-51$ & 7 & 17,50 \\
\hline $52-57$ & 3 & 7,50 \\
\hline TOTAL & $\mathbf{4 0}$ & $\mathbf{1 0 0}$
\end{tabular}

Sumber: Data Primer Setelah Diolah, 2020

Berdasarkan Tabel 1, klasifikasi umur responden berada dalam kategori umur produktif. Sebagian besar responden berada pada kisaran umur 22-27, 34-39, dan 40-45 tahun yakni sebanyak 8 orang atau sekitar 20 persen. Hal ini mendukung kegiatan usahatani jagung menjadi lebih produktif karena responden pada usia muda memiliki fisik yang potensial, kreatif dan lebih mudah menerima inovasi teknologi baru (Samun et al, 2011; Susanti, et al, 2016). Berkaitan dengan kegiatan usahatani, umur mempengaruhi pengambilan keputusan terkait pengelolaan lahan pertanian jagung. Responden dengan usia yang lebih tua cenderung memiliki pengalaman dan pertimbangan yang matang dalam pengambilan keputusan.

\section{Tingkat Pendidikan Responden}

Tingkat pendidikan responden menunjukkan wawasan dan pengetahuan yang dimilikinya. Seseorang dengan tingkat pendidikan yang tinggi bersikap lebih rasional dalam pengambilan keputusan. Pendidikan memberikan kemudahan dalam mengembangkan ide-ide, mudah mengadopsi teknologi dan bersikap dinamis terhadap perubahan (Husinsyah, 2014; Yulianti, 2015; Juliansyah dan Riyono, 2018).

Tabel 2. Klasifikasi Responden Menurut Tingkat Pendidikan, Tahun 2020

\begin{tabular}{ccc}
\hline Pendidikan & Jumlah Responden (Orang) & Persentase $(\%)$ \\
\hline SD & 30 & 75,00 \\
SMP & 4 & 10,00 \\
\hline SMA/SMK & 5 & 12,50 \\
S1 & 1 & 2,50 \\
\hline TOTAL & $\mathbf{4 0}$ & $\mathbf{1 0 0}$
\end{tabular}

Sumber: Data Primer Setelah Diolah, 2020

Berdasarkan Tabel 2, tingkat pendidikan responden masih rendah terhitung sebanyak 30 orang $(75 \%)$ berada pada Sekolah Dasar (SD). Sedangkan untuk tingkat 
Prosiding Seminar Nasional Pembangunan dan Pendidikan Vokasi Pertanian Politeknik Pembangunan Pertanian Manokwari, 14 November 2020

e ISSN : 2774-1982

pendidikan Strata 1 (S1) hanya sekitar 2,5\%. Tingkat pendidikan responden ini tidak hanya berkaitan dengan keputusan petani memilih teknik budidaya jagung tetapi lebih lanjut akan mempengaruhi pemasaran jagung. Hal ini berkaitan dengan kurangnya daya tawar petani. Penelitian Andriani et.al (2019) menjelaskan bahwa tingkat pendidikan yang rendah mempengaruhi keputusan petani dalam memilih pasar tujuan untuk menjual hasil panennya. Petani cenderung memilih menjual komoditinya pada pasar yang mudah dijangkau.

\section{Jumlah Tanggungan Keluarga Responden}

Jumlah tanggungan keluarga merupakan salah satu faktor yang mempengaruhi keputusan responden dalam berusahatani. Semakin banyak jumlah tanggungan keluarga maka semakin besar kebutuhan yang harus dipenuhi. Oleh karena itu, jumlah tanggungan keluarga mendorong responden untuk berproduksi dalam rangka meningkatkan pendapatan untuk memenuhi kebutuhan keluarganya (Hasyim, 2003; Mandang et al, 2020).

Tabel 3. Klasifikasi Responden Menurut Jumlah Tanggungan Keluarga, Tahun 2020

\begin{tabular}{ccc}
\hline $\begin{array}{c}\text { Tanggungan Keluarga } \\
\text { (orang) }\end{array}$ & Jumlah Responden (Orang) & Persentase (\%) \\
\hline $1-2$ & 13 & 32,50 \\
\hline $3-4$ & 21 & 52,50 \\
\hline $5-6$ & 5 & 12,50 \\
\hline $7-8$ & 1 & 2,50 \\
\hline TOTAL & $\mathbf{4 0}$ & $\mathbf{1 0 0}$ \\
\hline
\end{tabular}

Sumber: Data Primer Setelah Diolah, 2020

Berdasarkan Tabel 3, jumlah tanggungan responden cukup tinggi sekitar 3-4 orang $(52,5 \%)$. Jumlah tanggungan keluarga mempengaruhi kegiatan yang dilakukan responden, terutama berkaitan dengan pemasaran jagung. Di satu sisi tanggungan keluarga menjadi beban hidup yang mempengaruhi pendapatan petani tapi di sisi lain menjadi potensi sumber daya. Hal ini sesuai dengan penelitian Dahniar et al (2018) menjelaskan bahwa apabila tanggungan keluarga berada pada kelompok umur produktif, maka berpotensi menjadi tenaga kerja dalam kegiatan usahatani. Pada akhirnya, akan mengurangi pengeluaran untuk biaya tenaga kerja.

\section{Lama Berusahatani Responden}

Lama berusahatani mencerminkan pengalaman yang dimiliki petani responden. Pengalaman memegang peranan penting dalam kegiatan usahatani jagung. Semakin lama responden melakukan kegiatan usahatani maka dianggap semakin terampil dalam 
Prosiding Seminar Nasional Pembangunan dan Pendidikan Vokasi Pertanian Politeknik Pembangunan Pertanian Manokwari, 14 November 2020

e ISSN : 2774-1982

menguasai teknik budidaya, teknologi, hingga kegiatan pemasaran komoditi pertaniannya (Ratulangi et al, 2019).

Tabel 4. Klasifikasi Responden Menurut Lama Berusahatani Responden, Tahun 2020

\begin{tabular}{ccc}
\hline $\begin{array}{c}\text { Lama Berusahatani } \\
\text { (Tahun) }\end{array}$ & $\begin{array}{c}\text { Jumlah Responden } \\
\text { (Orang) }\end{array}$ & Persentase (\%) \\
\hline $5-9$ & 3 & 7,50 \\
\hline $10-14$ & 11 & 27,50 \\
\hline $15-19$ & 3 & 7,50 \\
\hline $20-24$ & 9 & 22,50 \\
\hline $25-29$ & 7 & 17,50 \\
\hline $30-35$ & 7 & 17,50 \\
\hline TOTAL & $\mathbf{4 0}$ & $\mathbf{1 0 0}$
\end{tabular}

Sumber: Data Primer Setelah Diolah, 2020

Berdasarkan Tabel 4, lama usahatani responden sebagian besar berada pada 1014 tahun (27,5\%). Pengalaman responden sangat membantu dalam pengambilan keputusan terutama berkaitan dengan usahatani jagungnya. Penelitian Dewi et al (2018) menjelaskan semakin tinggi pengalaman petani maka semakin mampu dalam mengatasi hambatan yang berkaitan dengan pengelolaan usahataninya.

\section{Kepemilikan Lahan}

Kepemilikan lahan sangat berperan penting terhadap keberlangsungan usahatani jagung. Lahan mempengruhi kapasitas produksi jagung yang dihasilkan responden. Dengan kata lain, semakin luas lahan yang dimiliki petani responden maka semakin besar pula jumlah jagung yang mampu diproduksi. Secara tidak langsung, luas lahan juga akan menentukan pendapatan rumah tangga petani (Maramba, 2018).

Tabel 5. Klasifikasi Responden Menurut Kepemilikan Lahan, Tahun 2020

\begin{tabular}{ccc}
\hline Luas Lahan (Hektar) & Jumlah Responden (Orang) & Persentase (\%) \\
\hline $0,5-1$ & 24 & 60 \\
\hline $1,5-2$ & 10 & 25 \\
\hline $2,5-3$ & 6 & 15 \\
\hline TOTAL & $\mathbf{4 0}$ & $\mathbf{1 0 0}$
\end{tabular}

Sumber: Data Primer Setelah Diolah, 2020

Berdasarkan Tabel 5, rata-rata petani responden memiliki lahan seluas 0,5-1 hektar atau sekitar 60 persen. Lahan jagung paling luas yang dimiliki responden dari 2,5 hektar hingga 3 hektar atau hanya sekitar 15 persen. Besarnya luas lahan mempengaruhi jumlah 
Prosiding Seminar Nasional Pembangunan dan Pendidikan Vokasi Pertanian

Politeknik Pembangunan Pertanian Manokwari, 14 November 2020

e ISSN : 2774-1982

jagung yang diproduksi dan yang akan dipasarkan. Rata-rata produksi jagung yang mampu dihasilkan petani responden sekitar 5,5 ton per hektarnya. Sesuai dengan penelitian Wahed (2015), luas lahan menjadi salah satu faktor utama dalam peningkatan produksi yang pada akhirnya dapat meningkatkan kesejahteraan petani.

\section{Analisis Data Penelitian}

\section{Penerimaan Usahatani}

Usahatani jagung yang dikelola petani responden di Kecamatan Patilanggio menghasilkan produksi yang cukup beragam. Produksi jagung dipengaruhi luas lahan garapan dan penggunaan input meliputi benih, pupuk, pestisida, dan tenaga kerja. Berikut ini disajikan hasil perhitungan rata-rata penerimaan usahatani jagung pada Tabel 6.

Tabel 6. Rata-rata Penerimaan Usahatani Jagung Per Musim Tanam di Kecamatan Patilanggio Kabupaten Pohuwato Provinsi Gorontalo, Tahun 2020

\begin{tabular}{llr}
\hline No & Uraian & Total \\
\hline 1. & Produksi $(\mathrm{kg})$ & 5.875 \\
2. & Harga $(\mathrm{Rp} / \mathrm{kg})$ & 3.143 \\
\hline & Penerimaan $[\mathbf{1 x 2}](\mathbf{R p})$ & $\mathbf{1 8 . 4 6 2 . 5 0 0}$
\end{tabular}

Sumber: Data primer setelah diolah, 2020

Berdasarkan Tabel 6, menunjukkan bahwa rata-rata jumlah produksi jagung tiap responden adalah $5.875 \mathrm{~kg} / \mathrm{MT}$. Jagung dijual dalam berbagai bentuk yakni jagung tongkol, pipilan basah, dan pipilan kering. Petani memasarkan jagung melalui pedagang pengumpul, BUMDES, dan pedagang besar diantaranya PT Harim dan PT Seger Agro Nusantara. Jagung dijual dengan harga rata-rata sebesar Rp 3.143,-/kg/MT. Maka tiap responden memperoleh penerimaan dari hasil penjualan jagung sebesar Rp 18.462.500,-/MT.

\section{Struktur Biaya Usahatani}

Biaya usahatani jagung yang dikeluarkan petani responden di Kecamatan Patilanggio meliputi biaya tetap dan biaya variabel. Komponen biaya tetap meliputi biaya sewa lahan dan penyusutan alat, sedangkan pajak lahan tidak dibebankan kepada petani jagung di Kecamatan Patilanggio. Komponen biaya variabel meliputi biaya penggunaan benih, pupuk, pestisida, dan tenaga kerja. Berikut ini rata-rata biaya usahatani jagung per musim tanam di Kecamatan Patilanggio disajikan pada Tabel 7. 
Prosiding Seminar Nasional Pembangunan dan Pendidikan Vokasi Pertanian Politeknik Pembangunan Pertanian Manokwari, 14 November 2020

e ISSN : 2774-1982

Tabel 7. Komponen Rata-Rata Biaya Tetap dan Biaya Variabel Usahatani Jagung Per Musim Tanam di Kecamatan Patilanggio Kabupaten Pohuwato Provinsi Gorontalo, Tahun 2020

\begin{tabular}{llr}
\hline No & Jenis Biaya & Total Biaya Rata-rata (Rp/MT) \\
\hline 1. & Biaya Tetap & \\
& Sewa Lahan & 75.000 \\
& Penyusutan Alat & 153.279 \\
\hline & Sub Total & $\mathbf{2 2 8 . 2 7 9}$ \\
\hline $\mathbf{2 .}$ & Biaya Variabel & \\
& Benih & 2.370 .000 \\
& Pupuk & 571.875 \\
& Pestisida & 376.450 \\
Tenaga Kerja & 2.598 .381 \\
\hline Sub Total & $\mathbf{5 . 9 1 6 . 7 0 6}$ \\
\hline Jumlah $(\mathbf{1 + 2})$ & $\mathbf{6 . 1 4 4 . 9 8 5}$
\end{tabular}

Sumber: Data primer setelah diolah, 2020

Berdasarkan Tabel 7 menunjukkan bahwa rata-rata biaya tetap usahatani jagung sebesar Rp 228.279,-/MT. Biaya tetap terdiri dari biaya sewa lahan sebesar Rp 75.000,-/ha dan biaya penyusutan alat sebesar Rp 153.279,-. Peralatan yang digunakan petani responden diantaranya cangkul, parang, sabit dan mesin pipil. Sedangkan rata-rata biaya variabel usahatani jagung sebesar Rp 5.916.706,-/MT. Biaya variabel terdiri dari biaya pembelian benih, penggunaan pupuk, pestisida, dan tenaga kerja. Petani responden menggunakan benih varietas Bisi 2, Bisi 18, dan NK, degan rata-rata biaya pembelian benih sebesar Rp 2.370.000,-/MT. Jenis pupuk yang digunakan petani responden yakni pupuk Urea, NPK, dan Phonska. Biaya yang dikeluarkan untuk penggunaan pupuk sebesar Rp $571.875,-/ \mathrm{MT}$.

Pestisida yang digunakan responden cukup beragam meliputi Rambo, Gramoxone, Noxone, Amandy, Calaris, Promotop, Kayabas dan Basmilang. Biaya penggunaan pestisida merupakan biaya terkecil diantara biaya variabel lainnya sebesar Rp 376.450,/MT. Sebaliknya, biaya variabel terbesar yakni biaya penggunaan tenaga kerja yang dialokasikan untuk pengolahan lahan, penanaman, pemupukan, pengendalian hama, dan panen dengan nilai rata-rata Rp 2.598.381,-/MT. Hasil analisis menunjukkan bahwa biaya variabel yang dikeluarkan lebih besar dibandingkan dengan biaya biaya tetap. Jadi total keseluruhan rata-rata biaya usahatani per musim tanam adalah Rp 6.144.985,-/MT. 
Prosiding Seminar Nasional Pembangunan dan Pendidikan Vokasi Pertanian Politeknik Pembangunan Pertanian Manokwari, 14 November 2020

e ISSN : 2774-1982

\section{Analisis Pendapatan dan Kelayakan Usahatani}

Pendapatan usahatani jagung di Kecamatan Patilanggio dihitung dari selisih hasil penjualan jagung (penerimaaan) dengan biaya usahatani yang dikeluarkan. Besarnya pendapatan tidak hanya dipengaruhi oleh besarnya produksi tetapi juga biaya usahatani. Maka pendapatan dianggap menguntungkan apabila penerimaan usahatani jagung lebih besar dibandingkan dengan biaya usahataninya. Secara rinci disajikan pada Tabel 8 .

Tabel 8. Rata-rata Pendapatan dan Kelayakan Usahatani Jagung Per Musim Tanam di Kecamatan Patilanggio Kabupaten Pohuwato Provinsi Gorontalo, Tahun 2020

\begin{tabular}{llr}
\hline No & Uraian & Total (Rp/MT) \\
\hline 1. & Penerimaan & 18.462 .500 \\
2. & Biaya & 6.144 .985 \\
\hline $\mathbf{1 .}$ & Pendapatan (1-2) & $\mathbf{1 2 . 3 1 7 . 5 1 5}$ \\
$\mathbf{2 .}$ & B/C ratio & $\mathbf{2}$ \\
\hline
\end{tabular}

Sumber: Data primer setelah diolah, 2020

Berdasarkan Tabel 8 menunjukkan bahwa total penerimaan yang diperoleh dari usahatani jagung adalah Rp 18.462.500,-/MT. Biaya usahatani yang dikeluarkan sebesar Rp 6.144.985,-/MT. Maka rata-rata pendapatan yang diperoleh petani responden sebesar Rp 12.317.515,-/MT. Nilai B/C ratio diperoleh sebesar 2, artinya setiap peningkatan biaya usahatani sebesar Rp 1.000,- akan menghasilkan pendapatan (benefit) sebesar Rp 2.000,Sehingga dapat disimpulkan bahwa usahatani jagung di Kecamatan Patilanggio menguntungkan dan layak dijalankan bagi petani responden.

\section{KESIMPULAN DAN SARAN}

Berdasarkan hasil analisis pendapatan dan kelayakan usahatani jagung di Kecamatan Patilanggio diperoleh rata-rata pendapatan responden sebesar $\mathrm{Rp}$ 12.317.515/MT dari total biaya sebesar Rp 6.144.985/MT. Analisis kelayakan menunjukkan nilai $\mathrm{B} / \mathrm{C}$ ratio sebesar 2, sehingga usahatani jagung di Kecamatan Patilanggio tergolong menguntungkan dan layak dijalankan. Adapun saran yang diperoleh dari penelitian ini diantaranya: petani diharapkan melakukan kegiatan pasca panen untuk menghasilkan jagung dengan kadar air rendah sehingga petani memperoleh harga jual yang tinggi, pemerintah diharapkan memfasilitasi terbentuknya BUMDES di setiap wilayah Provinsi Gorontalo sebagai lembaga yang membantu petani menjual hasil panennya. Dengan saran tersebut, dimaksudkan agar terjadi peningkatan pendapatan petani dari usahatani jagung. Sementara itu, untuk penelitian selanjutnya diharapkan mengkaji lebih jauh tentang faktor-faktor yang mempengaruhi produksi dan pendapatan usahatani jagung. 


\section{DAFTAR PUSTAKA}

Agustyari, N.K., Antara, I.M., \& Anggreni, I.G.A.A.L. (2013). Perbandingan Pendapatan Usahatani Jagung MAnis dan Padi di Subak Delod Sema Padanggalak Desa Kesiman Petilan Kecamatan Denpasar Timur. E-Jurnal Agribisnis dan Agrowisata, 2(4): 224235.

Andriani, R., Kusumo, B., Rasmikayati, E., Mukti, G.W., \& Fatimah, S. (2019). Faktorfaktor yang Mempengaruhi Keputusan Petani Mangga dalam Pemilihan Pasar di Kabupaten Indramayu. Jurnal Penyuluhan, 15(2): 286-298.

BPS Provinsi Gorontalo. (2018). Produksi Jagung Tiap Kabupaten 2010-2015. https://gorontalo.bps.go.id/subject/53/tanaman-pangan.html\#subjekViewTab5.

Diakses tanggal 1 Maret 2020.

BPS Kabupaten Pohuwato. (2016). Luas Panen dan Produksi Jagung Tiap Kecamatan 2011-2015. https://pohuwatokab.bps.go.id/subject/53/tanaman-pangan.html\#. Diakses tanggal 1 Maret 2020.

Dahniar., Makmur., \& Susanti, I. (2018). Analisis Tingkat Keuntungan Petani dan Pedagang Jagung Kuning (Zea mays) di Kecamatan Bontotiro Kabupaten Bulukumba. Agrovital, 3(2): 70-78.

Dewi, D.A.A., Darsono, \& Agustono. (2018). Analisis Efisiensi Pemasaran Jadung (Zea mays) di Kabupaten Wonogiri. Jurnal Agriecobis, 1(2): 23-33.

Ginting, Y.F., Rahmanta, \& Tarigan, K. (2020). Analysis of Factors Affecting the Income of Farmers of Corn (Zea mays) in The District of Tiga Binanga, Karo District. International Journal of Research and Review, 7(7): 206-211.

Hasyim, H. (2003). Analisis Hubungan Faktor Sosial Ekonomi Petani Terhadap Program Penyuluhan Pertanian. Laporan Hasil Penelitian. Medan: Universitas Sumatera Utara.

Husinsyah. (2014). Kontribusi Pendapatan Petani Karet Terhadap Pendapatan Petani di Kampung Mencimai. E-Jurnal EP Unud, 3(1)-9-20.

Juliansyah, H., \& Riyono, A. (2018). Pengaruh Produksi, Luas Lahan dan Tingkat Pendidikan Terhadap Pendapatan Petani Karet di Desa Bukit Hagu Kecamatan Lhoksukon Kabupaten Aceh Utara. Jurnal Ekonomi Pertanian Unimal, 1(2): 65-72.

Khairiyakh, R., Irham, \& Mulyo, J.H. (2015). Contribution of Agricultural Sector and Sub Sectors on Indonesian Economy. Ilmu Pertanian, 18(3): 150-159.

Mandang, M., Sondakh, M.F.L., \& Laoh, O.E.H. (2020). Karakteristik Petani Berlahan Sempit di Desa Tolok Kecamatan Tompaso. Jurnal Ilmiah Agrisosioekonomi, 16(1):105-114.

Maramba, U. (2018). Pengaruh Karakteristik Terhadap Pendapatan Usahatani Jagung di Kabupaten Sumba Timur (Studi Kasus: Desa Kiritana, Kecamatan Kambera, Kabupaten Sumba Timur). Jurnal Ekonomi Pertanian dan Agribisnis, 2(2): 94-101. 
Prosiding Seminar Nasional Pembangunan dan Pendidikan Vokasi Pertanian

Politeknik Pembangunan Pertanian Manokwari, 14 November 2020

e ISSN : 2774-1982

[NSLIC] National Support for Local Investment Climates. (2018). Kajian Ekonomi Komoditas Jagung Provinsi Gorontalo. Jakarta: World Trade Center.

Nugroho, B.A. (2015). Anaysis of Production Function and Efficiency of Corn at Patean District Kendal Regency. Journal of Economics and Policy, 8(2): 160-172.

Nurwibowo, M., Rahayu, E.S., \& Marwanti, S. (2013). Struktur dan Distribusi Pendapatan Rumah Tangga serta Strategi Kebijakan Peningkatan Kesejahteraan Petani Jagung di Lahan Perhutani di Kecamatan Tanggungharjo Kabupaten Grobogan Provinsi Jawa Tengah. Agribusiness Review, 1(1), 21-32.

Palobo, F., Masbaitubun, H., \& Tirajoh, S. (2019). Analisis Kelayakan Usahatani Jagung Hibrida pada Lahan Kering Di Merauke, Papua. SEPA: Jurnal Sosial Ekonomi Pertanian dan Agribisnis, 16(1), 1-10.

Prabowo, R. (2010). Kebijakan Pemerintah dalam Mewujudkan Ketahanan Pangan di Indonesia. MEDIAGRO, 6(2): 62-73.

Purwanto, A.Z.A., Hadayani, \& Muis, A. (2015). Analisis Produksi dan Pendapatan Usahatani Jagung Hibrida di Desa Modo Kecamatan Bukal Kabupaten Buol. Jurnal Agroland, 22(3): 205-215.

Ratulangi, D.H.A., Katiandagho, T.M., \& Sagay, B.A.B. (2019). Faktor-Faktor yang Mempengaruhi Keputusan Petani Menanam Jagung Manis dan Jagung Lokal. Jurnal Ilmiah Agrisosioekonomi, 15(3): 463-472.

Samun, S., Rukmana, D., \& Syam, S. (2011). Partisipasi petani dalam penerapan teknologi pertanian organik pada tanaman stroberi di Kabupaten Bantaeng. Jurnal Analisis Kebijakan Pertanian, 4(2), 1-12.

Sari, D.K., Haryono, D., \& Rosanti, N. (2014). Analisis Pendapatan dan Tingkat Kesejahteraan Rumah Tangga Petani Jagung di Kecamatan Natar Kabupaten Lampung Selatan. JIIA, 2(1): 64-70.

Setiawan, K., \& Basri, M. (2017). An Analysis of Efficiency the Production of Commodities Corn in Belu, East Nusa Tenggara, Indonesia. Journal of Environmental Science, Toxicology, and Food Technology, 11(10): 64-69.

Soekartawi, A. (2003). Teori Ekonomi Produksi dengan Pokok Bahasan Analisis Fungsi Cobb Douglas. Jakarta: Raja Grafindo Persada.

Suratiyah, K. 2006. Ilmu Usahatani. Jakarta: Penebar Swadaya.

Susanti, D., Listiana, N.H., \& Widayat, T. (2016). Pengaruh Umur Petani, Tingkat Pendidikan dan Luas Lahan Terhadap Hasil Produksi Tanaman Sembung. Jurnal Tumbuhan Obat, 9(2): 75-82.

Tahir, A.G., \& Suddin, A.F. (2017). Analisis Pendapatan Usahatani Jagung pada Lahan Sawah dan Tegalan di Kecamatan Ulaweng Kabupaten Bone Sulawesi Selatan. Jurnal Galung Tropika, 6(1): 1-11.

Ukkas, I. (2017). Faktor-Faktor yang Mempengaruhi Produktivitas Tenaga Kerja Industri Kecil Kota Palopo. Journal of Islamic Education Management, 2(2): 187-198. 
Prosiding Seminar Nasional Pembangunan dan Pendidikan Vokasi Pertanian

Politeknik Pembangunan Pertanian Manokwari, 14 November 2020

e ISSN : 2774-1982

Wahed, M. (2015). Pengaruh Luas Lahan, Produksi, Ketahanan Pangan dan Harga Gabah Terhadap Kesejahteraan Petani Padi di Kabupaten Pasuruan. JESP, 7(1): 68-74.

Yulianti, Ansofino, Jolianis. (2015). Analisis Faktor-Faktor yang Mempengaruhi Pendapatan Masyarakat Transmigrasi di Trans Sakato Jaya Kecamatan Sungai Aur Kabupaten Pasaman Barat, 1-9. 